\title{
Correction to: Prevention of unintentional injuries in children under five years
}

\author{
Sophie Jullien ${ }^{*}$
}

\section{Correction to: BMC Pediatr 21, 311 (2021) \\ https://doi.org/10.1186/s12887-021-02517-2}

After publication of this supplement article [1], it was brought to our attention that the article had published with a couple of errors in the reference list: firstly, references 35 and 43 had been combined into an incorrect version of reference 35; secondly, reference 67 has been erroneously omitted.

The references have since been corrected in the original article and may be found detailed below:

[35] NICE. Unintentional injuries on the road: interventions for under 15s [Internet]. 2010 [cited 2019 Oct 21]. p. 1-46. Available from: https://www.nice.org.uk/ guidance/ph31

[43] NICE. Unintentional injuries: prevention strategies for under 15s [Internet]. 2010 [cited 2019 Oct 21]. p. 1-88. Available from: https://www.nice.org.uk/guidance/ ph29

[67] Watson M, Kendrick D, Coupland C, Woods A, Futers D, Robinson J. Providing child safety equipment to prevent injuries: randomised controlled trial. BMJ. 2005;330:178-82.

The author apologizes for any inconvenience caused.
Reference
1. Jullien S. Prevention of unintentional injuries in children under five years.
BMC Pediatr. 2021;21:311 https://doi.org/10.1186/s12887-021-02517-2.

Published online: 06 October 2021

The original article can be found online at https://doi.org/10.1186/s12887021-02517-2.

*Correspondence: sophjullien@gmail.com

Barcelona Institute for Global Health, University of Barcelona, Barcelona,

Spain

(c) The Author(s) 2021. Open Access This article is licensed under a Creative Commons Attribution 4.0 International License, which permits use, sharing, adaptation, distribution and reproduction in any medium or format, as long as you give appropriate credit to the original author(s) and the source, provide a link to the Creative Commons licence, and indicate if changes were made. The images or other third party material in this article are included in the article's Creative Commons licence, unless indicated otherwise in a credit line to the material. If material is not included in the article's Creative Commons licence and your intended use is not permitted by statutory regulation or exceeds the permitted use, you will need to obtain permission directly from the copyright holder. To view a copy of this licence, visit http://creativecommons.org/licenses/by/4.0/. The Creative Commons Public Domain Dedication waiver (http://creativeco mmons.org/publicdomain/zero/1.0/) applies to the data made available in this article, unless otherwise stated in a credit line to the data. 